\title{
МОВОЗНАВСТВО
}

\section{ЛЕКСИЧНИЙ РЕГУЛЯТИВ ЛІС В ЕПІСТОЛЯРНИХ ТЕКСТАХ ЛЕСІ УКРАЇНКИ}

\author{
СВІТЛАНА БОГДАН \\ Східноєвропейський національний університет імені Лесі Українки, Луцьк - Україна \\ bohdan-s@ukr.net; ORCID: 0000-0002-4831-2770 \\ LEKSYKALNY REGULATYW LAS \\ W EPISTOLARNYCH TEKSTACH ŁESI UKRAINKI \\ SWITŁANA BOHDAN \\ Wschodnioeuropejski Uniwersytet Narodowy imienia Łesi Ukrainki, Łuck — Ukraina
}

STRESZCZENIE. W artykule omówiono jeden z dominujących zarówno w literackich, jak również epistolarnych tekstach Łesi Ukrainki obrazów-regulatywów las. Ustalono główne konteksty jego aktualizacji w dziedzictwie epistolarnym poetki. Przeanalizowano osobliwości modelowania przestrzeni semantycznej danego mikropola w jej indywidualnym stylu.

Słowa kluczowe: regulatyw las, mikropole, tekst epistolarny, twórczość językowa.

\section{LEXICAL REGULATIVE FOREST IN LESYA UKRAINKA'S EPISTOLARY TEXTS}

\section{SVITLANA BOHDAN \\ Lesya Ukrainka Eastern European National University, Lutsk — Ukraine}

ABSTRACT. The article deals with the regulative forest, one of the dominant imagesregulators of not only artistic, but also Lesya Ukrainka's epistolary texts. The main contexts of its updating in her letter heritage have been found. The peculiarities of the modelling of the semantic space of this microfield in her individual style have been analysed.

Key words: regulative forest, microfield, epistolary text, language creation.

$\mathrm{P}$

егулятивність як визначальну ознаку кожного тексту найвиразніше формують лексичні елементи ${ }^{1}$. 3 одного боку, саме вони моделюють стрижень семантичної основи тексту. А з іншого - слугують передумовою для творення основ індивідуально-стильових ознак тексту. Власне ці одиниці здебільшого вибудовують концептуальну канву ідіостилю, проектовану на національно-мовний простір. Цілком передбачувано за таких умов центром ключових понять у текстах певного автора виявляються ті, що співвіднесені 3 особливостями його мовомисленння, ландшафту, у якому він народився чи в якому довелося перебувати (постійно / фрагментарно) упродовж життя. Скажімо, якщо для одних письменників в експлікації геопростору домінувальним у їхніх текстах виявляється степ, для інших — море чи гори ${ }^{2}$, то мовна особис-

${ }^{1}$ Н. С. Болотнова, Регулятивность, [в:] Стилистический энциклопедический словарь русского языка, Москва 2003, с. 328-331; Н. С. Болотнова, И. И. Бабенко и др., Коммуникативная стилистика текста: лексическая регулятивность в текстовой деятельности, Томск 2011.

${ }^{2}$ О. С. Сфименко, Конщепт “степ” в украйнській мові: словникова, текстова і психолінгвістична парадигма, автореф. дис ... канд. филол. наук, Харків 2005. 
тість Лесі Українки асоціюється передусім із регулятивом ліс. Ідеться не лише про іiі художні тексти (і зрозуміло, що саме Лісова пісня в такому контексті неминуче буде передбачуваним асоціатом щодо іï імені чи навпаки), а й про епістолярні, що засвідчують наскрізність, тобто власне регулятивність актуалізації цієї лексеми й інших елементів указаного лексико-словотвірного ряду, що утворюють цілісне семантичне мікрополе.

Згадуючи неповторну драму-фейєрію, нагадаємо насамперед Лесин авто-

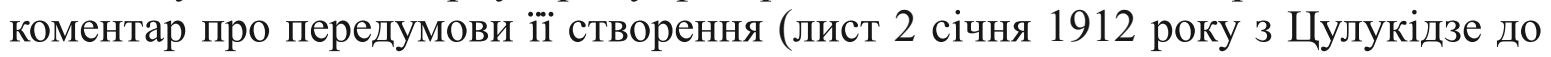
матері Ольги Косач-Драгоманової), щоб переконатися у визначальності цього образу в системі іiі емоцій, відчуттів і почуттів, а не лише художньої творчості, порівн.: Мені здається, що я просто згадала намі ліси та затужила за ними. А то ще я й здавна тую мавку “в умі держала”, ще аж із того часу, як ти в Жабориці мені щзось про мавок розказувала, як ми йшли якимсь лісом з маленькими, але дуже рясними деревами. Потім я в Колодяжному в місячну ніч бігала самотою в ліс (ви того ніхто не знали) і там ждала, щзоб мені привиділася мавказ Щоправда, у листі 27 жовтня 1911 року з Цулукідзе до іншого адресата, приятеля Агатангела Кримського, вона зауважує, що хоч волинські ліси (швидше - їхній клімат) й мали негативний вплив на iї здоров'я, але саме вони слугували спонукою й мотивацією її появи, порівн.: Треба було в Сгипті вродитись, то, може, й був би лад, але ж найгірша помилка мого життя - се щзо я зросла у волинських лісах, решта все тільки логічні наслідки. А проте я не згадую лихом волинських лісів. Сього літа, згадавши про їх, написала “драму-феєрію” на честь їм, і вона дала мені багато радощів, хоч я й відхорувала за неї (без сього вже не йде!) ${ }^{4}$.

Номен ліс, як відомо, належить до визначальних й узвичаєних в українському мовопросторі елементів концептуальної картини світу й особливих ознак українського ландшафту (традиційно цю лексему тлумачать як “велику площу землі, зарослу деревами і кущами” або “певну ділянку такої площі”,), що й зумовлює частотність його використання в різних типах текстів.

Номінацію ліс, що, безперечно, $є$ ядерною одиницею в цьому лексикосемантичному мікрополі, Леся Українка актуалізує, щоправда, не часто (35 разів у збережених епістолярних текстах); ще рідше вона використовувала похідні прикметники - лісова / лісовий (8), Лісова пісня - 12, лісничий - 3. Спорадично вжито також номени гай, кущзі та чагарi, що представлені факультативно. Органічно доповнюють це лексико-семантичне мікрополе окремі групи, що вербалізують номени дерево та квіти. Однак кількісні параметри не позбавляють це мікрополе семантичної значущості.

Уперше лексему ліс ужито у вересневому листі 1889 року до брата Михайла (Тілько щзо ходила в ліс, споглядати красу осіннеі природи, а вернувиись зараз сідаю писать тобі) ${ }^{6}$, у якому фіксуємо виразну асоціативну співвіднесеність і взаємозумовленість: ліс - естетична насолода, поки що лише з актуалізацією зовнішніх, зорових відчуттів, про що свідчить дієслово споглядати (у СУМ-і дієслово споглядати тлумачать так: “дивитися на кого-, що-небудь, розглядати когось, щось. Ходила в ліс споглядати красу осінньої природи (Леся Українка,

\footnotetext{
${ }^{3}$ Леся Українка, Зібрання творів, у 12 томах, Київ 1975-1979, т. XII, с. 378.

${ }^{4}$ Там само, с. 373.

${ }^{5}$ Словник украӥнської мови, в 11 томах, ред. колег. І. К. Білодід (голова), П. Й. Горецький та ін., Київ 1970-1980, т. IV, с. 522.

${ }^{6}$ Леся Українка, Листи: 1876-1897, Київ 2016, с. 68.
} 
$\mathrm{V}, 1956,17)$ "7). Як бачимо, перше значення наведеного слова подано з покликанням саме на цей епістолярний контекст Лесі Українки, щоправда, редагований відповідно до сучасних норм.

Лic у іiі епістолярних текстах, подібно до поетичних і драматургійних, духовна субстанція зі своєю ієрархією взаємозв'язків, що слугують засобом гармонізації світу природи, у якому людина є лише одним з його компонентів. Власне тому узвичаєна й найбільш бажана для Лесі ситуація усамітнення - перебування в лісі, про що, зокрема, вона пише в листі до Л. Драгоманової (Колодяжне, 29.VIII (10.IX).1895): А так би часом хотілось побродити самій по лісі, по тих місиях, де стільки споминів літає поміж деревами... Я вся тепер у спогадах

Цілком передбачувано в епістолярних текстах Лесі Українки знайшли відображення не лише певні універсальні для різних національно-мовних картин семантичні характеристики цього номена, і не так образні (як це можна спостерігати в іії художніх текстах), а насамперед ті, що виявляють психоемоційний стан адресантки, особливості ії сприйняття, а також оцінювальні ознаки, на яких позначився вплив не так фактора первинного географічного середовища, у якому вона перебувала з дитинства (хоча він і був одним з визначальних у системі іiі координат співіснування з природою), як культура родинного середовища, зорієнтована на гармонійну взаємодію зі світом природи (Косачівські діти, як відомо 3 епістолярних текстів, мемуаристики ${ }^{9}$, Хронології О. Косач-Кривинюк, ${ }^{10}$ долучалися до вирощування квітів, висаджування дерев (Мын насадылы багачько квітокъ і малы зъ нымы дуже багацько морокы, зато теперъ воны вже почынають ивісти ${ }^{11}$ (до бабусі Слизавети Драгоманової, Колодяжне, червень 1884 р.)). Однак, як зауважувала Леся в одному з листів до М. Драгоманова, вона була більшою мірою, аніж будь-хто з інших дітей, відірвана від землі (Тимчасом Олеся гребеться у садку мов курка, все садить, та пересажує, та насажує, на се йде той час, що зостається від науки. Взагалі у нас усі діти в землі риються з охотою, тілько я до землі не схиляюсь, а все десь пробуваю в небесних сферах. Одбилась я від землі певне на віки! Не знаю, чи мені на се жаль, чи ні... ${ }^{12}$ (до М. Драгоманова, квітень-травень 1893 р.)). Однак ліс з раннього дитинства став органічною часточкою ï єства й буття, тому згадка про нього, за іiі зізнанням, стала визначальним мотивом Лісової nicнi.

Центр мовного образу лісу становить сема 'простір' (або його частина). Вона репрезентована здебільшого мікроконтекстами, що створюють його сукупний образ і сприйняття як цілісності, на противагу менш уживаному - одиничному, основу якого становить окреме дерево як назва мікрогрупи цього лексико-семантичного мікрополя (як родова назва) чи вияв конкретизованого його різновиду (видова назва), напр., верба, сосна, смерека, ялина, пальма, кипарис, мандарини тощо.

Не менш характеристичні для їі епістолярного ідіостилю й ті мікроконтексти, що актуалізують сему 'ліс як живий організм', напр., ліс гомонить, лісовий гомін, лісовий ритм, тобто метафоризовані одиниці. А отже, у Лесі Українки номен ліс є й носієм семи антропоморфності, слугує засобом розширення його загальномовної сполучуваності.

\footnotetext{
${ }^{7}$ Словник украӥнської мови ... т. IX, с. 555.

8 Леся Українка, Листи: 1876-1897 ..., с. 376.

9 Спогади про Лесю Украӥнку, Нью-Йорк-Київ 2017.

${ }^{10}$ О.П.Косач-Кри винюк, Леся Украӥнка. Хронологія життя і творчості, Луцьк 2006.

${ }^{11}$ Леся Українка, Листи: 1876-1897 ..., с. 48.

${ }^{12}$ Там само, с. 198.
} 
Для епістолярної комунікації Лесі Українки визначальні два основні типи антропоморфізації цієї номінації - завдяки прикметниковим і дієслівним метафорам. Власне такі метафоричні одиниці - продуктивний засіб персоніфікації в усій українській мовній практиці й передусім у поетичній ${ }^{13}$, що сягає, безперечно, давніх українських уснопоетичних традицій і пов'язана з антропоморфічними уявленнями наших пращурів (тобто з “наділенням предметів і явищ природи, небесних тіл, тварин, міфічних істот зовнішністю і фізичними властивостями людини" 14 , вірою в те, що все живе має душу, зокрема дерево, квітка, кожна рослина. Як зазначає В. Жайворонок, „у народній уяві дерево - жива істота, яка навіть розмовляє; лісові сили розуміють мову дерев (див. Лісову nicню Лесі Українки"15).

Унікальна спостережливість Лесі Українки, ії уміння виокремити виразні ознаки лісу відтворені в листі із Сан-Ремо (31. XII. 1902 (13. I. 1903)) до Івана Франка, у якому йдеться про ії міркування й зауваження щодо поеми Лiсова ідилія, зокрема про неточності в його описах і як наслідок - штучність мовно-стильових характеристик: $B$ діалогу мені все приходилось примущувати себе вірити, що ліс може так довго і складно росповісти иілий той випадок з князем, княгинею еtс. Само по собі те оповідання не зле, але щоб його Вам ліс отак knapp und gebunden (детально і послідовно (нім.)) розповів, то не вкладається в мою фантазію. I лісовий ритм я собі не октавами представляю, - океан ще може мати октави, бо в хвилях його все ж єсть якийсь лад і закон, а ліс, мені здається, “верлібрист" і ніколи не скандує своїх віршів. Ще дві-три октави ліс може б і вдав при погожому вітрі, але - $16{ }^{16}$. У цьому мікроконтексті привертає увагу акцентована Лесею відповідальність автора за творення художніх образів, що жодним чином, на їі переконання, не повинні містити щонайменшої фальші. Перифраз ліс-верлібрист актуалізує, очевидно, сему 'непередбачуваність', указує на постійну змінюваність, неповторність і “безладність” лісового голосу, лісового співу й лісових розмов (саме цей контекст, імовірно, можна вважати першопочатком чи точкою відліку в створенні образу “лісової пісні”).

Однією з найважливіших у ії листовних текстах можна вважати атрибутивну характеристику ключового номена ліс. Найбільш індивідуально увиразнені ті з них, що містять такі ознаки: 1) різновид лісу — пальмові ліси: Вже мене біда загнала ось у які пальмові ліси... ${ }^{17}$ (на листівці зображено пальми $з$ підписом „Tra le palme. San-Remo” (Серед пальм. Сан-Ремо (італ.)); 2) відношення до місця розташування - волинські ліси: $A$ проте я не згадую лихом волинських лісів ${ }^{18}$; 3) сприйняття адресантки та їі оцінки - чудові ліси: Вид на хутірську балку і на близькі ліси чудовий ${ }^{19}$. Іноді такі ознаки подано в поєднанні, напр., в описі околиць Зеленого Гаю, містини, що, за словами Лесі Українки, могла би бути взірцем “українійшої України”: Мої сестри (їх у мене три) покажуть Вам всю околищю, побачите вже таку Украӥну, що “украінійшої” й нема. Гойдаючись в гамаках попід дубами, прочитаємо Вамі нові твори, а мої хіба старі,

${ }^{13}$ Л. С. Прокопов ич, Номінаиї̈ сад, ліс у поетичних текстах Ліни Костенко, [в:] „Лінгвістичні дослідження", Луцьк 2012, вип. 34, с. 197-201.

${ }^{14}$ Словник іншомовних слів, Київ 1985, с. 70.

${ }^{15}$ В. В. Жай воронок, Знаки української етнокультури, словник-довідник, Київ 2006, с. 175.

${ }^{16}$ Леся Українка, Листи: 1898-1902, Київ 2017, с. 525.

${ }^{17}$ Там само, с. 357.

${ }^{18}$ Леся Українка, Зібрання творів... т. XII, с. 373.

${ }^{19}$ Там само, с. 68. 
бо нових тим часом дасть Біг. Ви, може, що нового тут напищете, лісовий гомін, може, навіє на Вас нові мрії та думки. Наша хата оточена лісом, а нижче по річиі ліс ще більший, не смерековий, правда, а мішаний, але темний $i$ гар$\boldsymbol{н и и ̆ ~ ( т у т ~ і ~ д а л і ~ в и р і з н е н н я ~ в ~ ц и т а т а х ~ м о і ̈ . ~ - ~ С . ~ Б . ~}{ }^{20}$. Принагідно звернемо увагу й на метафору лісовий гомін, що визначає ще один особливий статус лісу — мотиватор, передумова творчості.

Спостережено також, що саме номен ліс нерідко є складником формування адвербіальних структур (і лише факультативно - об'єктних), що належать до одного із засобів локальних характеристик простору, де перебуває сама адресантка (рідко - iї друзі чи знайомі), напр.: А хтось $і$ так уже трохи застудився, приїхавши, спочатку на Сириі (у Драгоманових), - то такий собі хутір

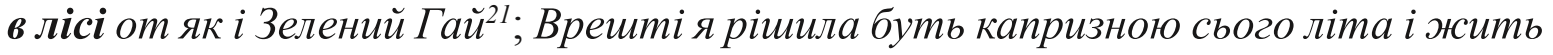
не там де случиться, а де сподобається. А що до ціни, то де не живи в Криму, чі в лісі, чі на піску, все одно дешево не вийде [I, с. 441] (до О. А. ТесленкоПриходько, Київ, 17 (29). V. 1897). Саме ці локативні експлікації мають здебільшого порівняльні контексти рідного й чужого в Лесиних листах, із цілком передбачуваним стилістичним маркером позитиву на користь природніх для неї локацій, як-от: Отже, тепер я не над морем, хоч і під ясним небом, тепер я над лиманом Дністровим біля города Акермана у франиузькій колонії в Шабі... Жити тут нічого собі, тілько досить скучно, то вже нема що казати, але врешті не скучніше, ніж в Свпаторії. Краще б я хотіла тепер бути коло Вас у ваших лісах, аніж отут “ходити понад лиманами”...22 (до М. Драгоманова, Шабо, 22. VIII (3. IX). 1891).

Лic, подібно до морського узбережжя, - бажане для Лесі місце писання листів: Тепер я пишу в самій “натуральній” обстановці, в лісі (за 50 шагів від моєї хати) під величезною смерекою і навколо самі тілько дерева та папороть, птиці співають, Черемош шумить, а з ним навперейми шумить отой залізний поток, що то власне Буркутом зветься. Якби не сей шум, було б зовсім тихо, людей не чуть, вітру нема (він тут рідко буває, гори не пускають). Як я тут не поправлюсь, то вже не знаю, якого мені клімату тре$6 a^{23}$ (до батька, Буркут, 12 (25). VII. 1901). Цитований контекст дає можливість реконструювати не лише особливості пейзажу (посередництвом усього номінативного ланцюжка: смереки - папороть - спів птищь - шум Черемоша - залізний потік (Буркут)), а й емоційний стан адресантки, суголосний такій ситуації.

Із-поміж атрибутивних словосполучень 3 дериватом лісовий фіксовано лише кілька: лісова натура, лісова душа, лісові квітки й лісова пісня, три з яких $\epsilon$ елементом ії автохарактеристики, четверте - стосується одного з найвідоміших іiі творів. Мабуть, не випадково метафоричний образ-самохарактеристика “лісова натура" актуалізовано за особливих умов перебування Лесі Українки в Берліні (під час операції в клініці професора Бергмана): Шкода, що, як ти кажеш, дом в хуторі (ідеться про будинок поблизу Гадяча, на хуторі Зелений Гай. - прим.) не буде до кіния іюня скінчений. Але ж я думаю все таки, що властиве я могтиму там одразу поселитись з ким-небудь, признаться, мені сього більше хочеться, ніж сидіти в самому Гадячі, дуже я тут, серед камінно-

\footnotetext{
${ }^{20}$ Там само, с. 151 .

${ }^{21}$ Там само, с. 467.

22 Леся Українка, Листи: 1876-1897 ..., с. 153.

23 Леся Українка, Листи: 1898-1902..., с. 296.
} 
го Берліна заскучала за лісом, таки лісова натура обзивається ${ }^{24}$ (до П. А. Косача, Берлін, 1 (13). V. 1899). Експліковано цей перифраз-самохарактеристику в контексті типологічного для ії мовотворчості стилістичного прийому бінарного опозитування: Зелений Гай — камінний Берлін, що увиразнює його не лише як домінантну ознаку автопортретування, а й ту, яку можна визначити як "природжену", тобто органічну, на противагу топосу міста — як чужого, не властивого їй.

Подібний семантичний простір має й інший метафоричний образ - “лісова душа”, який фіксуємо в листі з болгарської Владаї до дядька М. Драгоманова: „E! я на дереве!” (Леся Українка згадала випадок з дитинства, коли, сидячи на дереві, щось схоже вигукувала до дядька, який приїхав в гості до Косачів) або принаймі під деревом і на горі. Моя лісова душа заспокойлась, дерева єсть, чагарі єсть - чого ж іще? ${ }^{25}$ (Владая, [7] 19. VII. 1894). Лише серед природи гір, потоку, дерев, чагарів - вона знаходила рівновагу, що відтворено метафорою душа заспокоӥлася. Кваліфікатив лісова сьогодні навряд чи хто спроможеться сприйняти лише як чергову образну номінацію, принаймні в Лесиному автопортретуванні й окресленні іiі Alter ego.

Прикметник лісовий утворює в одному з ії епістолярних текстів ще одну стилістично окреслену образну словосполуку - лісові квітки, що слугує засобом інтекстової характеристики їі творчості. Такий перифраз, як стверджує Леся, уживала щодо ііі творів мати, Олена Пчілка (Звісно, якби я вміла продавати не так рукописи, як “вдохновенье”, то, може б, досі з самих “авторських" забагатіла, та коли ж маю таку прокляту натуру, що замість "хлебных пьес" вирошую з серия якісь лісові, мовляла ти, “квітки”, а з квіток же, відомо, хліба не їсти..."26 (до матері, 25 березня 1912 р., Кутаїсі). Мікроконтекст експлікації цього образного найменування утворено на протиставленні Лесиних творів і “хлебных пьес” інших авторів як таких, що позбавлені заздалегідь фінансової винагороди й прибутків на противагу всім тим, що пишуться заради хліба насущного.

Найбільш поширений й асоціативно співвіднесений з їі текстом образ лісової nicнi фіксований у листовних текстах хоч і частотно, однак лише як бібліонім, тобто як назва книжки. Контексти його вживання змістово різнорідні: від звичайної констатації факту написання й мотивації створення - до відгуків й описів рецепцій цього твору в тодішньому українському соціумі. Виокремимо особливе ставлення авторки до цього твору як до живої сутності, власної дитини, що не можна кваліфікувати лише як ще один елемент персоніфікації чи мовної гри, а як реальні особистісні переживання (Я недавно послала Люді всякі “матеріали” і прошу ї̈ наглядати, щуоб актори не дуже “обидили” мою “Лісову пісню”, але чи се в силі людській?.. ${ }^{27}$ (Людя - донька Михайла Старицького, у листі йдеться про ймовірну постановку драми на сцені)). За твердженням Лесі Українки, подібне ставлення до цього твору було властиве й для Климента Квітки, тобто його можна кваліфікувати як симетричне: Tenep сеє очарування (образом Мавки. - С. Б.) передалось і Кльоні - він якось відноситься до сеї поеми, як до живої людини, — мені аж чудно... ${ }^{28}$. Зрештою, така мовна поведінка Лесі Українки проектована й на інші їі тексти (див. детальніше в попе-

\footnotetext{
${ }^{24}$ Там само, с. 123.

25 Леся Українка, Листи: 1876-1897..., с. 293.

26 Леся Українка, Зібрання творів ..., т. XII, с. 388.

${ }^{27}$ Там само, с. 409.

${ }^{28}$ Там само, с. 379.
} 
редніх стаття $\mathrm{x}^{29}$ ). Саме цю ознаку можна вважати типологічною для комунікативної поведінки письменника в ставленні до власних творів, що частково відображає загальномовну українську мовно-стильову парадигму в таких ситуаціях (згадаймо хоча б відповідні поетичні рефлексії й контексти Тараса Шевченка).

Процес створення цієї драми Леся Українка визначає як горіння (Хоч і докінчить (мусить, бо вже обічяв ту річ), то тямить добре, що то не буде таке, $я$ як, наприклад, “Лісова пісня" або "Камінний господар " (хтось був би рад, якби хтось чорненький ті дві речі прочитав, бо люди кажуть, що то найліпше з усього хтосевого доробку), бо хтось не горить тепер так, як горів над тими двома драмами ${ }^{30}$ [XII, с. 456]). Однак номінацію горіла сприймаємо в цьому мікроконтексті як реальний стан авторки, а не метафоричний. Зрештою, його можна вважати узвичаєним для неї, якщо йдеться про стан написання кожної драми: "Лісову пісню" я потім так відхорувала, що боялася повороту зимової історії, інші речі менших нападів коштували, але жадна не минула дарма, - вже нехай ніхто не скаже, що я “ні горівщи, ні болівши” здобуваю собі “лаври”, бо таки в буквальному значенні горю й болію кожнісінький раз ${ }^{31}$. Як наслідок - уже типологічно - виснаження, загострення хвороби, порівн. хоча б кілька інших тематично подібних контекстів: ...nисала я ї̈ (Лісову пісню. С. Б.) дуже недовго, 10-12 днів, і не писати ніяк не могла, бо такий уже був непереможний настрій; але після неї я була хвора і досить довго "приходила до пам'яті" "32. Се ж і єсть ота Märchendraта, що я не знала, як ї̈̈назвати. Після неї я, відхорувавши, скільки належалось, написала одноактівку знов з римсько-християнським колоритом (III cm.), потім уже захворіла як слідод різдва до великодня - на гостре запалення нирок ${ }^{33}$; потім я знову лежу zusammengeklappt (розслаблена (нім.), як порожня торбина. Отак я писала “Лісову пісню” $і$ все, що писала остатнього року"34. В останньому прикладі психофізичний стан авторки увиразнено за допомогою порівняння, що актуалізує сему 'спустошення', 'остаточне виснаження'.

Стрижневим в авторському ставленні до цієї драми беззастережно є атрибутив “неравнодушна”, тобто небайдужа (Та не думай, однак, що я мало ціню уважне читання з руки ближчої родини, ні, я його иүіню найбільше, ие я зовсім щиро кажу, і успіх "Лісової пісні" серед вас вважаю за великий тріумф собі, тим більще щзо я його не сподівалась чогось. Мені здавалось, що ти (мама. С. Б.) не похваляєш такого стилю (ти не радила мені писати фантастичні драми з інших причин, але мені здавалось, що й "по существу" ти мала щось против того, хоч тепер бачу, щзо я помилялась). А я таки сама "неравнодушна" до сеї речі, бо вона мені дала стільки дорогих хвилин екстазу, як мало яка інша" 35$)$. Одна 3 мотиваційних передумов такого особливого ставлення - найвищі емоційні переживання авторки в момент іiі створення (екстаз — "крайній,

${ }^{29}$ С. Богдан, Номінативне поле лексичного регулятива дитина в епістолярних текстах Лесі Українки, [в:] „Науковий вісник Східноєвропейського національного ун-ту ім. Лесі Українки. Серія «Філологічні науки (мовознавство)»", 2015, № 6, с. 6-12; С. Богдан, Оказіональні найменування номінативного поля дитина в епістолярних текстах Лесі Українки, [в:] „Лінгвостилістичні студіі”, наук. журн., Луцьк 2015, вип. 3, с. 6-36.

30 Леся Українка, Зібрання творів..., т. XII, с. 456.

${ }^{31}$ Там само, с. 380.

32 Там само, с. 374 .

${ }^{33}$ Там само, с. 396.

${ }^{34}$ Там само, с. 394.

35 Там само, с. 378 . 
найвищий ступінь захоплення"36). Оцінювальний спектр цього твору в українському соціумі (неофіційному, засвідченому в Лесиних листах) репрезентовано кількома стилістично маркованими лексемами, що мають спільну інтегральну сему 'досконалий' - шедевр (Я і про “Лісову пісню” думала, щзо всі тільки сміятимуться з сеї “старомодної романтики”, а ї̈, здається, признано за мій chef d'oеuvre (шедевр (франц.)) ${ }^{37}$ [XII, с. 414]) і найліпше (.. бо люди кажуть, щзо то ("Лісова пісня" й "Камінний господар". — С. Б.) найліпше з усього хтосевого доробку $\left.{ }^{38}\right)$. Однак щонайбільшу втіху авторка мала від похвали та визнання цієї драми в родині. Зокрема, у листі до матері 2 січня 1912 року із Цулукідзе вона зізнавалася, що ... успіх “Лісової пісні” серед вас вважаю за великий тріумф собі, тим більше щзо я його не сподівалась чогось ${ }^{39}$ (порівн.: Несподіваний був для мене успіх фантастики серед авдиторії старшої родини - людей, вихованих в традиціях реалізму, - але тим краще"40), хоча первинне прилюдне мовчання щодо драми ії насторожувало. Ці контексти семантично співзвучні іншому Лесиному одкровенню в листі до сестри Ольги 29 грудня 1911 р. про те, що можна стати пророком хоча б у своїй родині, якщо не судилося у своїй країні: Кожен “пророк” таки найбільше домагається “слави в отчизні своїй і серед родини своєі”, може, саме тому, щзо сього найтрудніше осягти ${ }^{41}$, порівн. також ще одну лексико-синтаксичну трансформацію цього відомого афоризму як коментар щодо оцінок їі творчості братом Михайлом: Міша то смішить мене навіть своїми дифірамбами; певне, то неправда, щчо не можна бути пророком в рідному краю, бо, отже, можна ним бути навіть в очах рідного брата ${ }^{42}$.

Кілька разів Леся вживає в листах номінацію лісничий, що відображає тогочасну мовну практику називання цієї професії: Я живу в меншому, в домі у лісничого, де крім мене ще є одна пані приїзжа, а то лісничий з жінкою і дитиною, тай більи нікого"нз.

Лексема дерево як родове найменування має подібні мікроконтексти вживання, що й ліс. Один 3 найвиразніших - атрибутивне словосполучення скрипуче дерево в системі автопортретування Лесі Українки, зокрема самономінація скрипуче дерево, що є узвичаєним українським фразеологізмом (узуально вживані всі три синоніми, щоправда, з різною частотністю актуалізації - скриnучий, скриплячий і скрипливий: „Скрипливий, а, е. Те саме, що скрипу́чий 1, 2. Скрипливе дерево довго живе (Укр.. присл.., 1955, 145)”"44; „, Скрипу́чий, a, е.1. Який скрипить, утворює скрип...). Скрипуче колесо довще ходить (Укр. присл.., 1955, 146)" "45, зокрема, усіченим варіантом одного 3 поширених на Західному Поліссі дотепер - скрипуче дерево два віка живе. Переносно цей атрибутив уживають у характеристиках щодо недужої або хворобливої людини. У листах Лесі Українки така характеристика експлікує водночас семи 'стійкість' і 'довговічність'. Саме тому ця самономінація актуалізує одну з іiі диференційних рис - оптимізм. Фіксовано чотири контексти вживання цієї лексеми, порівн.: На вид я та же, что и при Вас, но чувствую себя совстм больной.

\footnotetext{
${ }^{36}$ Словник української мови ..., т. II, с. 465.

37 Леся Українка, Зібрання творів ..., т. XII, с. 414.

${ }^{38}$ там само, с. 456.

39 Там само, с. 378 .

${ }^{40}$ Там само, с. 375 .

${ }^{41}$ Там само, с. 375 .

42 Леся Українка, Листи: 1876-1897 ..., с. 173

43 Леся Українка, Листи: 1898-1902 ..., с. 295.

${ }^{44}$ Словник української мови ..., т. IX, с. 320.

45 Там само, с. 321.
} 
Впрочем, конечно, выдержу и это, как выдержала в свое время многое дру-

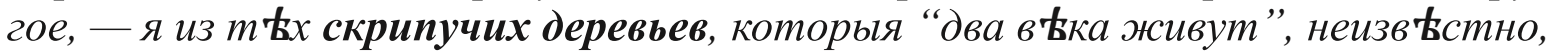
для какого благополучія... ${ }^{46}$ (до Є. М. Чирикова, Київ, 30.III (12.IV).1901); Лілея моя! Дуже мені жаль, щзо не застану вже тебе в Києві, ну, але за те зобачиш мене здоровою. Бачиш, я таки справжнє те скрипуче дерево, що два віки живе... ${ }^{47}$ (до сестри Ольги, Чернівці, 2 (15).IX.1901). Двічі в епістолярних текстах цей фразеологізм актуалізовано повністю, до того ж графічні маркери підкреслюють його гетерогенність: Будьте ж ласкаві та пишіть мені частіше хоч карточки. А за мене будьте спокійні я “скрипуче дерево, щзо два віки живе”48 (до М. В. Кривинюка, Сан-Ремо, 14 (27). II. 1902); I взагалi ich habe zähes Leben (я чіпка до життя (нім.)), як всі Косачі, і хоч би й зовсім не лічилась, то таки б не хутко пропала, а буду лічитися не для того, аби не згинути (того я так хутко не боюся), а для того, щзоб жити людиною, а не “скрипучим деревом, що два віки живе” та обидва без користі ${ }^{49}$ (до Л. М. Драгоманової-Шишманової, СанРемо, 1 (14).V.1902). Найповніше Лесину вітавістичність стверджує останній із цитованих фрагментів - лист до двоюрідної сестри Лідії, у якому, усупереч усім попереднім твердженням про свій хворобливий статус, вона заперечує цю номінацію: іiї не приваблює життя без можливості почуватися вповні людиною.

Цілком передбачувано мікрополе ліс у листах Лесі Українки поєднане з іншими, важливими для українського макросвіту лексико-семантичними полями, що мають регулярний вияв у різних типах текстів, і корелюють 3 ним, зокрема із садом і полем, але це вже тема іншого дослідження.

Отже, мікрополе ліс має хоч і нечастотне (порівняно з іншими лексикосемантичними полями), проте вагоме місце в семантичному просторі епістолярних текстів Лесі Українки, оскільки слугує основою пізнання специфіки відображення не лише національної МКС в ії мовотворчості, а й елементом автопортретування. Вербалізація цього регулятива в і1і листах співвіднесена з узвичаєною й домінувальною для традиційного українського сприйняття природи ознакою - антропоморфізмом. Естетизація номена ліс як початку й передумови природньої духової зрівноваженості, традиційна для української ментальності й усього національного мовомислення та мовного простору, має виняткову роль у їі особистісному самопізнанні та ідентифікації й виокремленні внутрішніх рис. До того ж ліс - один з найбільш властивих для неї локусів перебування й побутування.

\section{Список використаної літератури}

Богдан С., Номінативне поле лексичного регулятива дитина в епістолярних текстах Лесі Украӥнки, [в:] „Науковий вісник Східноєвропейського національного ун-ту ім. Лесі Українки. Серія «Філологічні науки (мовознавство)»”, 2015, № 6, с. 6-12.

Богдан С., Оказіональні найменування номінативного поля дитина в епістолярних текстах Лесі Украӥнки, [в:] „Лінгвостилістичні студії”, наук. журн., Луцьк 2015, вип. 3, c. 6-36.

Болотнова Н. С., Бабенко И. И. и др., Коммуникативная стилистика текста: лексическая регулятивность в текстовой деятельности, коллект. моногр., Томск 2011.

Болотнова Н. С., Регулятивность, [в:] Стилистический энцииклопедический словарь русского языка, Москва 2003, с. 328-331.

\footnotetext{
46 Леся Українка, Листи: 1898-1902 ..., с. 245.

47 Там само, с. 317.

48 Там само, с. 402 .

49 Там само, с. 450 .
} 
Єфименко О. Є., Кониепт “степ” в украӥнській мові: словникова, текстова і психолінгвістична парадигма, автореф. дис ... канд. филол. наук, Харків 2005.

Жайворонок В. В., Знаки української етнокультури, словник-довідник, Київ 2006.

Косач-Кривинюк О. П., Леся Українка. Хронологія життя і творчості, Луцьк 2006.

Прокопович Л. С., Номінаиї сад, ліс у поетичних текстах Ліни Костенко, [в:] „Лінгвістичні дослідження”, Луцьк 2012, вип. 34, с. 197-201.

Словник іншомовних слів, Київ 1985.

Словник української мови, в 11 томах, ред. колег. І. К. Білодід (голова), П. Й. Горецький та ін., Київ 1970-1980.

Спогади про Лесю Українку, Нью-Йорк-Київ 2017.

Леся Українка, Зібрання творів, у 12 томах, Київ 1975-1979.

Леся Українка, Листи: 1876-1897, Київ 2016.

Леся Українка, Листи: 1898-1902, Київ 2017.

\section{Spysok vykorystanoi literatury [References]}

Bohdan S., Nominatyvne pole leksychnoho rehuliatyva dytyna $v$ epistoliarnykh tekstakh Lesi Ukrainky [Nominative Field of Lexical Regulative "Child" in Epistolary Texts by Lesya Ukrainka], [v:] „Naukovyi visnyk Skhidnoievropeiskoho natsionalnoho un-tu im. Lesi Ukrainky. Seriia «Filolohichni nauky (movoznavstvo)»", 2015, № 6, s. 6-12.

Bohdan S., Okazionalni naimenuvannia nominatyvnoho polia dytyna $v$ epistoliarnykh tekstakh Lesi Ukrainky [Occasional Names of Nominative Field "Child" in Epistolary Texts by Lesya Ukrainka], [v:] „Linhvostylistychni studii”: nauk. zhurn., Lutsk 2015, vyp. 3, s. 6-36.

Bolotnova N. S., Babenko Y. Y. i dr., Kommunikativnaya stilistika teksta: leksicheskaya regulyativnost'v tekstovoj deyatel'nosti, kollekt. monogr. [Communicative Stylistics of Text: Lexical Regularity in Text Activity], Tomsk 2011.

Bolotnova N. S., Regulyativnost' [Regularity], [v:] Stilisticheskij enciklopedicheskij slovar' russkogo yazyka, Moskva 2003, s. 328-331.

Yefymenko O. Ye., Kontsept "step" v ukrainskii movi: slovnykova, tekstova i psykholinhvistychna paradyhma [Concept "Step" in Ukrainian: Vocabulary, Text and Psychological Paradigm]: avtoref. dys. ... kand. filol. nauk, Kharkiv 2005.

Zhaivoronok V. V., Znaky ukrainskoi etnokultury [Signs of Ukrainian Ethnic Culture], slovnyk-dovidnyk, Kyiv 2006.

Kosach-Kryvyniuk O. P., Lesia Ukrainka. Khronolohiia zhyttia i tvorchosti [Lesya Ukrainka. Chronology of Life and Creative Work], Lutsk 2006.

Prokopovych L. S., Nominatsii sad, lis u poetychnykh tekstakh Liny Kostenko [Nominations "Garden”, “Forest” in Poetic Texts by Lina Kostenko], [v:] „Linhvistychni doslidzhennia", Lutsk 2012, vyp. 34, s. 197-201.

Slovnyk inshomovnykh sliv [Dictionary of Foreign Words], Kyiv 1985.

Slovnyk ukrainskoi movy [Dictionary of the Ukrainian Language], v 11 tomakh, red. koleh.

I. K. Bilodid (holova), P. Y. Horetskyi ta in., Kyiv 1970-1980.

Spohady pro Lesiu Ukrainku [Recollections about Lesya Ukrainka], Niu-York-Kyiv 2017.

Lesia Ukrainka, Zibrannia tvoriv [Collection of Works], u 12 tomakh, Kyiv 1975-1979.

Lesia Ukrainka, Lysty: 1876-1897 [Letters], Kyiv 2016.

Lesia Ukrainka, Lysty: 1898-1902 [Letters], Kyiv 2017. 